\title{
PENGARUH KOMITMEN ORGANISASI TERHADAP ORGANISAZIONAL CITIZENSHIP BEHAVIOR (OCB) PEGAWAI PADA BPTPM KOTA PEKANBARU
}

\author{
Rony Jaya \\ Dosen Fakultas Ekonomi dan Ilmu Sosial \\ Universitas Islam Negeri Sulthan Syarif Kasim Riau \\ email: rony.jaya@uin-suska.ac.id
}

\begin{abstract}
Abstrak
Penelitian ini bertujuan untuk mengetahui dan menganalisis pengaruh komitmen organisasi terhadap Perilaku Kewarganegaraan Karyawan pada BPTPM Kota Pekanbaru. Metode penelitian ini menggunakan pendekatan kuantitatif. Peneliti mengambil sampel secara random (random sampling) sebanyak 46 karyawan sebagai sampel dari 85 karyawan. Teknik pengumpulan data menggunakan kuesioner. Metode analisis data menggunakan regresi sederhana dengan menggunakan software SPSS versi 21. Hasilnya menunjukkan bahwa komitmen organisasi berpengaruh secara signifikan terhadap perilaku kewarganegaraan pegawai pegawai (OCB) di BPTPM Pekanbaru CIty. Kondisi ini menunjukkan jika komitmen organisasi meningkat, pegawai BPTPM Organizational Citizenship Behavior (OCB) juga meningkat. Variabel komitmen organisasi berkontribusi terhadap variabel perilaku Kewarganegaraan Organisasi sebanyak 65,2\%. Dengan demikian, sisanya 34,8\% merupakan faktor lain yang tidak diteliti dalam penelitian ini.
\end{abstract}

Kata kunci: Komitmen Organisasi, Organizational Citizenship Behavior (OCB)

\section{PENDAHULUAN}

Organisasi sebagai wadah kerjasama bagi manusia dalam usaha mencapai sasaran perlu mendapat dukungan sumber daya dalam menjalankan aktivitasnya. Sumber daya utama yang menjadi penentu keberhasilan organisasi adalah sumber daya manusia (Human capital) baik secara kulitas maupun kuantitasnya. Baik organisasi private maupun publik tentu menginginkan sumber daya manusia (pegawai/karyawan) yang berkinerja tinggi dan sesuai dengan kebutuhan organisasi dalam menghadapi persaingan. Kinerja individu secara kolektif inilah yang akan menentukan kinerja organisasi secara keseluruhan dalam rangka pencapaiaan sasaran.

Di Indonesia Sumber daya manusia pada organisasi publik selalu mendapat sorotan. Sorotan berupa pandangan negatif terhadap pelaksanaan pelayanan publik oleh pegawai telah menjadi rahasia umum.
Perbaikan kualitas pelayanan instansi publik secara kontinu terus dilakukan oleh pemerintah seperti agenda reformasi birokrasi. Reformasi birokrasi merupakan bentuk upaya pemerintah untuk meningkatkan kualitas pelayanan melalui debirokratisasi dan penempatan pegawai sesuai dengan kompentensi. Salah satunya dengan memperketat proses penerimaan dan promosi pegawai. Pegawai yang menduduki jabatan diharapkan memiliki kualifikasi dan kompentensi yang sesuai dengan kebutuhan jabatan dan mampu melaksanakan tugas sesuai dengan deskripsi kerja (job description).

Pegawai yang melaksanakan tugas sesuai job description akan membantu organisasi (instansi publik) dalam rangka mencapai sasaran. Terlebih mereka yang melaksanakan tugas tersebut dengan penuh rasa tanggung jawab dan bersedia melakukan hal lebih bagi organisasinya dengan sukarela. Organ dan Bateman dalam 
Titisari (2014) mengungkapkan perilaku pegawai yang diharapkan organisasi tidak hanya mencakup in-role yaitu bekerja sesuai dengan standart job description saja namun juga ekstra-role yaitu memberikan organisasi lebih dari pada yang diharapkan. Melaksanakan tugas melebihi tuntutan pekerjaan (ekstra-role) inilah dikenal dengan istilah Organisazional Citizenship Behavior (OCB).

Menurut Darto (2014) dalam era reformasi birokrasi sebagaimana saat ini sedang dijalankan diberbagai intansi pemerintahan, peran OCB dianggap vital dan sangat menentukan kinerja organisasi. Selain sebagi unsur yang unik dari perilaku yang unik dalam dunia kerja, OCB juga menjadi aspek yang hampir jarang terjadi dalam lingkup aparatur pemerintahan. Karena OCB menjadi karakteristik individu yang tidak hanya mencakup kemampuan dan kemauannya mengerjakan tugas pokoknya saja namun juga mau melakukan tugas ekstra seperti kehendak untuk melakukan kerjasama dengan pegawai lainnya, suka menolong, memberikan saran, berpartisipasi secara aktif, memberikan pelayanan ekstra kepada pengguna layanan, serta mau menggunakan waktu kerjanya secara efektif.

Realitanya memang perilaku OCB pegawai sulit dan jarang ditemui pada instansi publik. Walaupun dirasakan masih langka dan jarang ditemui, tetapi munculnya OCB menjadi hal yang positif bagi instansi publik termasuk pada Badan Pelayananan Terpadu dan Penanaman Modal (BPTPM) Kota Pekanbaru. BPTPM Kota Pekanbaru merupakan suatu badan yang dibentuk pemerintah kota Pekanbaru sebagai wujud keinginan untuk lebih meningkatkan pelayanan prima kepada masyarakat. Badan Pelayanan Terpadu dan Penanaman Modal (BPTPM) Kota Pekanbaru memilki tugas pokok melaksanakan sebagian urusan pemerintahan daerah kota dalam bidang perizinan dan non perizinan. BPTPM mewakili pelayanan beberapa instansi lainnya di kota Pekanbaru. Hal ini dimaksudkan untuk mempermudah masyarakat dalam mendapatkan pelayanan dalam satu pintu. Dengan demikian BPTPM Kota Pekanbaru menjadi salah satu. Organisasi pemerintah digaris terdepan yang bersentuhan langsung dengan kepentingan masyarakat dalam memberikan pelayanan dan tentu akan menjadi sorotan.

Perilaku OCB muncul dari kemauan diri dan secara sukarela. Akan menjadi hal yang positif jika Instansi publik seperti BPTPM Kota Pekanbaru memiliki pegawai dengan perilaku OCB. Menurut Markozy dalam Titisari (2014), Karyawan yang baik (good citizen) adalah cendrung untuk menampilkan Organisazional Citizenship Behavior (OCB) dilingkungan kerjanya, sehingga organisasi akan lebih baik dengan adanya karyawan yang bertindak atau menampikan perilaku OCB.

Menarik untuk dikaji, faktor yang dapat memicu munculnya OCB pegawai salah satunya adalah komitmen organisasi. Menurut referensi teori dan beberapa hasil penelitian komitmen organisasi berpengaruh secara signifikan terhadap munculnya OCB. Budiardjo (2014) menyatakan komitmen organisasi berkorelasi secara signifikan terhadap OCB. Pernyataan School dan Schappe (dalam Purba, 2004) yang menemukan bahwa komitmen organisasi berpengaruh positif dan signifikan terhadap OCB. Hasil ini diperkuat lagi dengan hasil penelitian Purba (2004) yang hasil penelitiannya menunjukan bahwa diketahui komitmen organisasi berpengaruh cukup besar terhadap OCB di Indonesia.

$$
\text { Luthans dalam Sutrisno (2013) }
$$

menyatakan komitmen organisasi diindikasikan dalam tiga hal, yaitu keinginan kuat seseorang untuk tetap menjadi anggota organisasinya; kemauan untuk mengarahkan usahanya untuk organisasinya; serta keyakinan dan penerimaan yang kuat terhadap nilai-nilai dan tujuan organisasi. Komitmen organisasi akan membuat pegawai memberikan yang terbaik kepada organisasinya. Pegawai yang memiliki komitmen yang tinggi akan lebih 
berorientasi pada kerja, akan cendrung membantu dan dapat bekerjasama, yang merupakan bagian dari sikap Organizational Citizenship Behavior (OCB).

Berdasarkan teori dan hasil penelitian sebelumnya jelas komitmen organisasi berpengaruh dan memberikan kontribusi terhadap munculnya OCB. Tujuan penelitian ini adalah untuk mengetahui dan menganalisis seberapa besar pengaruh tersebut antara komitmen organisasi terhadap Organizational Citizenship Behavior (OCB) pegawai pada Badan Pelayananan Terpadu dan Penanaman Modal (BPTPM) Kota Pekanbaru.

\section{LANDASAN TEORI}

\subsection{Pengertian Komitmen Organisasi}

Komitmen organisasi merupakan bentuk adanya ikatan antara anggota dan organisasinya atau antara pegawai dengan instansi publik tempatnya bekerja. Dalam literatur terdapat beragam defenisi tentang komitmen organisasi. Antara lain Menurut Mathis dan Jackson dalam Sopiah (2014) komitmen organisasi adalah derajat yang mana karyawan percaya dan menerima tujuan-tujuan organisasi dan akan tetap tinggal atau tidak akan meninggalkan organisasi.

Menurut Mowday, Porter dan Steer dalam Darmawan (2013) menjelaskan komitmen organisasi adalah kuatnya pengenalan dan keterlibatan seseorang dalam suatu organisasi tertentu. Newstroom dalam Sopiah (2014) melanjutkan bahwa secara konseptual, komitmen organisasional ditandai oleh tiga hal : (1) Adanya rasa percaya yang kuat dan penerimaan sesorang terhadap tujuan dan nilai-nilai organisasi. (2) Adanya keinginan seseorang untuk melakukan usaha secara sungguh-sungguh demi organisasi. (3) adanya hasrat yang kuat untuk mempertahankan keanggotaan dalam suatu organisasi.

Selanjutnya Luthans dalam Sutrisno (2013) menyatakan komitmen organisasi merupakan (1) keinginan yang kuat untuk menjadi anggota dalam suatu kelompok, (2)
Kemauan usaha yang tinggi untuk organisasi, (3) suatu keyakinan tertentu dan penerimaan terhadap nilai-nilai dan tujuantujuan organisasi. Ketiga poin yang dijelaskannya akan menjelaskan tinggi rendahnya keterikatan antara individu dan organisasinya.

Komitmen organisai oleh Allen dan Mayer dalam Titisari (2014) juga diidentifikasi menjadi tiga kelompok yaitu:

1. Komitmen afektif (affective commitment)

Komitmen afektif mengacu pada emosi yang melekat pada karyawan untuk mengidentifikasi dan melibatkan dirinya dengan organisasi. Karyawan dengan komitmen afektif yang kuat cendrung secara terus menerus akan setia pada organisasi karena memang begitu keinginan mereka yang sebenarnya ada dalam hati mereka.

2. Komitmen Normatif (Normative commitment)

Komitmen normatif mengacu pada refleksi perasaan akan kewajiban untuk menjadi karyawan perusahaan. Karyawan dengan komitmen normatif yang tinggi merasa mereka memang seharusnya tetap bekerja pada organisasi tempat mereka bekerja sekarang.

3. Komitmen berkelanjutan (Continuance commitment)

Komitmen yang berkelanjutan mengacu kepada kesadaran karyawan yang berkaitan dengan akibat meninggalkan organisasi.

Menurut Sutrisno (2013) konsep komitmen organisasi sangat terkait erat dengan kenapa orang bergabung dalam kelompok. Sebagai mahluk sosial manusia selalu termotivasi untuk berinteraksi dengan manusia lainnya. Dengan motivasi ini terbentuklah sejumlah macam bentuk kelompok. Menurut teori reinforcement orang memasuki kelompok karena ingin mendapatkan reward, artinya ia akan memperoleh keuntungan langsung seperti uang ataupun kekuasaan. Seseorang juga termotivasi untuk masuk kelompok karena 
kelompok bisa dijadikan alat untuk mendapatkan keuntungan yang diperoleh diluar kelompok tersebut misalnya ingin dekat dengan pejabat, maka ia memasuki organisasi tertentu sehingga bisa berinteraksi dengan pejabat yang diharapakan. Kalau semua itu diperoleh anggota maka komitmen organisasi dapat tercapai.

\subsection{Pengertian OCB}

Istilah OCB diperkenalkan oleh Organ diawal tahun 1980-an. Namun jauh sebelum tahun tersebut Bernard, (1938) telah menggunakan konsep sejenis OCB dan menyebutnya sebagai kerelaan bekerjasama (willingness to coorperate). Pada tahun 1964 Katz menggunakan konsep serupa dan menyebutnya sebagai inovatif dan perilaku spontan (innovative and spontaneous behaviours). Secara singkat, OCB menunjukan suatu perilaku sukarela individu (dalam hal ini karyawan) yang secara tidak langsung berkaitan dengan sistem pengimbalan namun berkontrubusi pada keefektifan organisasi. Dengan kata lain OCB merupakan perilaku seseorang karyawan bukan karena tuntutan tugasnya namun lebih didasarkan pada kesukarelannya (Budiardjo, 2014).

Beberapa defenisi mengenai OCB juga diungkapkan oleh oleh para ahli lainnya, salah satunya oleh Robbins \& Judge dalam Waspodo (2012) mendefinisikan OCB sebagai perilaku pilihan yang tidak menjadi bagian dari kewajiban kerja formal seorang karyawan, namun mendukung berfungsinya organisasi tersebut secara efektif. Menurut Aldag dan Rasckhe dalam Titisari (2014) Organizational Citizenship Behavior (OCB) merupakan kontribusi individu yang melebihi tuntutan peran di tempat kerja. Organizational Citizenship Behavior (OCB) ini melibatkan beberapa perilaku meliputi menolong orang lain, menjadi volunteer untuk tugas-tugas kerja, patuh terhadap aturan-aturan dan prosedurprosedur di tempat kerja. Perilaku ini menggambarkan "nilai tambah karyawan" yang merupakan bentuk perilaku prososial, yaitu perilaku yang positif, konstruktif dan bermakna membantu.

Johns dalam Budiardjo (2014) mengemukakan bahwa OCB memiliki karakteristik perilaku sukarela (extra-role behaviours) yang tidak termasuk dalam urusan jabatan, perilaku spontan/ tanpa sasaran atau perintah seseorang, perilaku yang bersifat menolong serta perilaku yang tidak mudah terlihat serta dinilai melalui evaluasi kinerja. Adapun perilaku yang dapat diukur berdasarkan dimensi OCB menurut Organ yang dikutip dalam Titisari (2014) dapat diketahui dengan melihat perilaku berdasarkan dimensi Organizational Citizenship Behavior (OCB) yaitu :

1. Altruism

Perilaku karyawan dalam menolong rekan kerjanya yang mengalami kesulitan dalam situasi yang sedang dihadapi baik mengenai tugas dalam organisasi maupun masalah pribadi orang lain. Dimensi ini mengarah kepada memberi pertolongan yang bukan merupakan kewajiban yang ditanggungnya.

2. Conscientiousness

Perilaku yang ditunjukan dengan berusaha melebihi yang diharapkan perusahaan. Perilaku sukarela yang bukan merupakan kewajiban atau tugas karyawan. Dimensi ini menjangkau jauh diatas dan jauh kedepan dari panggilan tugas.

3. Sportmanship,

Perilaku yang memberikan toleransi terhadap keadaan yang kurang ideal dalam organisasi tanpa mengajukan keberatan-keberatan. Seseorang yang mempunya tingkatan yang tinggi dalam sportmanship akan meningkatkan iklim yang positif diantara karyawan, karyawan akan lebih sopan dan bekerjasama dengan yang lain sehingga akan menciptakan lingkungan kerja yang lebih menyenangkan.

4. Courtessy

Menjaga hubungan baik dengan kerjanya agar terhindar dari masalah-masalah 
interpersonal. Seseorang yang memiliki dimensi ini adalah orang yang menghargai dan memerhatikan orang lain.

5. Civic Virtue,

Perilaku yang mengindikasikan tanggung jawab pada kehidupan organisasi (mengikuti perubahan dalam organisasi, mengambil inisiatif untuk merekomendasikan bagaimana operasi atau prosedur-prosedur organisasi dapat diperbaiki, dan melindungi sumbersumber yang dimiliki organisasi). Dimensi ini mengarah kepada tanggung jawab yang diberikan organisasi kepada seseorang untuk meningkatkan kualitas bidang pekerjaan yang ditekuni.

\subsection{Hipotesis}

Dalam penelitian ini terdapat dua variabel yang akan diukur. Yaitu variabel komitmen organisasi sebagai variabel bebas (x) dan variabel Organizational Citizenship Behavior (OCB) (y) sebagai variabel terikat atau variabel yang dipengaruhi. Hipotesis dalam penelitian ini adalah "diduga Komitmen organisasi berpengaruh positif dan signifikan terhadap Organizational Citizenship Behavior

(OCB) pegawai pada Badan Pelayanan Terpadu dan Penanaman Modal (BPTPM) Kota Pekanbaru". Maka ketentuan hasil pengujian adalah sebagai berikut :

$\mathrm{Ho}=$ Tidak terdapat pengaruh yang signifikan antara Komitmen Organisasi terhadap OCB pegawai pada BPTPM Kota Pekanbaru

$\mathrm{Ha}=$ Terdapat pengaruh yang signifikan antara Komitmen Organisasi terhadap OCB pegawai pada BPTPM Kota Pekanbaru

\section{METODE}

Metode penelitian ini menggunakan pendekatan kuantitatif. Adapun tempat penelitian adalah pada kantor Badan Pelayanan Terpadu dan Penanamana Modal (BPTPM) Kota Pekanbaru. Responden penelitian ini adalah 46 pegawai sebagai sampel yang diambil secara acak (random sampling) dari populasi penelitian berjumlah 85 orang pegawai. Sampel didapat dengan perhitungan menggunakan rumus Slovin (dalam Umar, 2002). Teknik pengumpulan data dilakukan dengan penyebaran kuisoner yang diisi oleh responden pegawai. Analisis data menggunakan regresi sederhana dengan bantuan aplikasi SPSS versi 21.

\section{HASIL PENGUJIAN}

\subsection{Deskripsi Statistik Variabel Penelitian}

Dari hasil penelitian, dapat diketahui deskripsi statistik untuk masing-masing variabel baik variabel komitmen organisasi maupun variabel Organizational Citizenship Behavior (OCB). Adapun hasil Deskripsi statistik didapat dari hasil skor rata-rata (mean) masing-masing variabel penelitian yang dijelaskan pada tabel 1 berikut ini :

Tabel 1. Mean Skor Variabel Penelitian

\begin{tabular}{|l|l|c|}
\hline \multicolumn{1}{|c|}{ Variabel } & \multicolumn{1}{c|}{ Mean } & Ket. \\
\hline Komitmen Organisasi & 4,08 & Tinggi \\
\hline OCB & 4,19 & Tinggi \\
\hline
\end{tabular}

Dari tabel 1 dapat diketahui
bahwasanya pegawai pada Pelayanan Terpadu dan Penanamana Modal (BPTPM) memiliki komitmen organisasi dan Organizational Citizenship Behavior (OCB) pada katagori tinggi. Komitmen organisasi yang memperoleh skor rata-rata tinggi mengindikasikan pegawai BPTPM kota pekanbaru memiliki kesamaan nilainilai yang erat dengan organisasinya sehingga tatap bertahan dan setia dalam menjalankan kewajiban sebagai pegawai mengingat resiko meninggalkan organisasi akan lebih besar.

\section{Variabel Organizational Citizenship} Behavior (OCB) juga mendapat skor ratarata pada katagori tinggi. Ini mengindikasikan pegawai BPTPM Kota Pekanbaru juga telah menunjukan perilaku OCB dalam menjalankan pekerjaan seperti adanya perilaku suka menolong pekerjaan pegawai lainnya, memberikan saran, berpartisipasi secara aktif dalam pertemuan, memberikan pelayanan ekstra kepada 
pengguna layanan, serta mau menggunakan waktu kerjanya secara efektif.

\subsection{Uji Validitas}

Pengujian validitas dilakukan untuk mengetahui tingkat validitas instrumen. Semakin tinggi validitasnya maka instrumen tersebut menunjukkan semakin mengenai sasarannya, atau semakin menunjukkan apa yang seharusnya diukur. Pengujian ini dilakukan pada per-item pertanyaan yang berupa pernyataan responden menganai komitmen organisasi (x) dan Organizational Citizenship Behavior (OCB) (y). Nilai validitas dapat dilihat pada kolom Pearson Correlation. Jika angka korelasi yang diperoleh lebih besar dari pada angka kritik ( $r$ hitung $>r$ tabel ) maka instrumen tersebut dikatakan valid. Nilai $r$ tabel pada taraf signifikansi $5 \%$ adalah 0.291 .

Tabel 2. Hasil Uji Validitas

\begin{tabular}{|c|c|c|c|}
\hline Variabel & Item & $\begin{array}{c}\text { Pearson } \\
\text { Correlation }\end{array}$ & Ket. \\
\hline \multirow[t]{6}{*}{$\mathrm{KO}(\mathrm{x})$} & (x). 1 & 0.596 & Valid \\
\hline & (x). 2 & 0.732 & Valid \\
\hline & (x).3 & 0.477 & Valid \\
\hline & (x).4 & 0.887 & Valid \\
\hline & $(\mathrm{x}) .5$ & 0.779 & Valid \\
\hline & (x).6 & 0.770 & Valid \\
\hline \multirow{15}{*}{$\begin{array}{l}\text { OCB } \\
(y)\end{array}$} & (y).1 & 0.732 & Valid \\
\hline & (y). 2 & 0.573 & Valid \\
\hline & (y). 3 & 0.725 & Valid \\
\hline & (y). 4 & 0.736 & Valid \\
\hline & (y).5 & 0.682 & Valid \\
\hline & (y).6 & 0.752 & Valid \\
\hline & (y).7 & 0.668 & Valid \\
\hline & (y).8 & 0.680 & Valid \\
\hline & (y).9 & 0.580 & Valid \\
\hline & (y).10 & 0.625 & Valid \\
\hline & (y).11 & 0.535 & Valid \\
\hline & (y).12 & 0.677 & Valid \\
\hline & (y).13 & 0.620 & Valid \\
\hline & (y).14 & 0.694 & Valid \\
\hline & (y).15 & 0.295 & Valid \\
\hline
\end{tabular}

Berdasarkan hasil uji validitas maka seleluruh item pernyataan baik pada variabel komitmen organisasi maupun OCB memenuhu persayaratan. Artinya instrumen ini layak digunakan dan dinyatakan valid.

\subsection{Uji Reliabelitas}

Suatu Instrumen kuisioner dikatakan reliabel atau handal jika jawaban seseorang terhadap pernyataan adalah konsisten dari waktu ke waktu. Pengujian dilakukan dengan cara melihat nilai Cronbach Alpha (á). Jika Nilai Cronbach Alpha (á) variabel lebih besar dari 0.60 dapat disimpulkan instrumen kuisoner tersebut reliabel. Tabel 3 Berikut merupakan hasil uji reliabelitasnya.

Tabel 3. Hasil Uji Reliabelitas

\begin{tabular}{|l|l|l|}
\hline \multicolumn{1}{|c|}{ Variabel } & $\begin{array}{c}\text { Cronbach's } \\
\text { Alpha }\end{array}$ & \multicolumn{1}{c|}{ Ket. } \\
\hline KO $(\mathrm{x})$ & 0.803 & Reliabel \\
\hline OCB $(\mathrm{y})$ & 0.894 & Reliabel \\
\hline
\end{tabular}

Dari tabel 3 diketahui nilai Cronbach Alpha masing-masing varibel baik variabel komitmen organisasi maupun Organizational Citizenship Behavior (OCB) mendapatkan nilai yang lebih besar dari 0.60. Artinya intrumen penelitian ini reliabel dan layak digunakan.

\subsection{Uji Asumsi Klasik}

\subsubsection{Uji Normalitas}

Uji normalitas dapat dilihat pada diagram pencar hasil olah data SPSS dengan ketentuan bahwa apabila data menyebar disekitar garis diagonal dan mengikuti arah garis diagonal, maka model tersebut memenuhi asumsi normalitas dan sebaliknya jika data menyebar jauh dari garis diagonal maka model tidak memenuhi asumsi normalitas. Gambar 1 berikut menunjukan hasil uji normalitas data penelitian.

Gambar 1. Hasil Uji Nomalitas

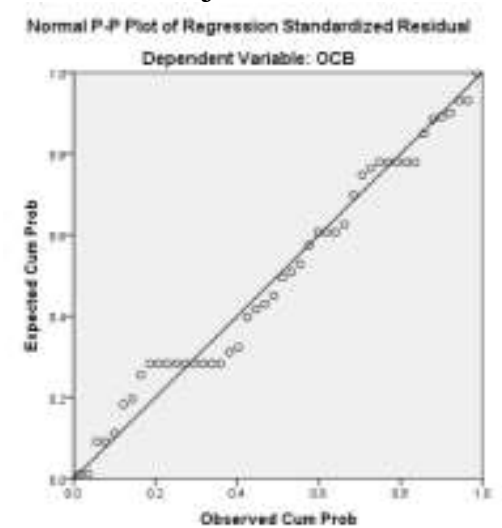

Berdasarkan gambar 1 maka dapat dilihat data menyebar disekitar garis 
diagonal. Hal ini menunjukan bahwa model regresi pada penelitian ini memiliki distribusi data yang normal. Kesimpulannya data memenuhi asumsi normalitas sehingga layak digunakan.

\subsubsection{Uji Heteroskedastisitas}

Hasil uji Heteroskedastisitas pengolahan data dengan menggunakan SPSS ditunjukan oleh gambar scatterplot dengan Regression Studentized Residual sebagaimana pada gambar 2 berikut :

Gambar 1. Hasil Uji Heteroskedastisitas

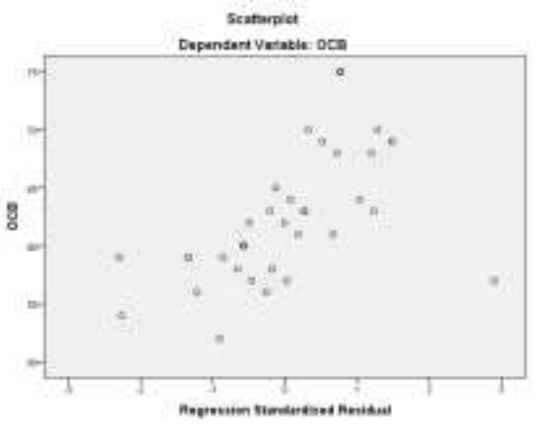

Dari Gambar 2 terlihat titik yang menyebar yang tidak membentuk pola-pola tertentu dan tersebar baik dibawah angka 0 pada sumbu Regression Studentized Residual (y) dan berdasarkan gambar tersebut maka tidak terjadi heteroskedastisitas sehingga model regresi layak dipakai untuk memprediksi Organizational Citizenship Behavior (OCB).

\subsection{Regeresi Sederhana}

Regeresi sederhana digunakan untuk menganalisis pengaruh variabel komitmen organisasi terhadap variabel Organizational Citizenship Behavior (OCB) Setelah data memenuhi persyaratan dan layak maka dilakukan analisis regeresi lenier sederhana dengan menggunakan bantuan SPSS v.21. Hasil pengolahan data dapat dilihat pada tabel 4 berikut ini.

Tabel 4. Hasil regeresi sederhana

Coefficients $^{\mathrm{a}}$

\begin{tabular}{|c|c|c|c|c|c|}
\hline \multirow{2}{*}{ Model } & \multicolumn{2}{|c|}{ Unstandardized Coefficients } & \multirow{2}{*}{\begin{tabular}{|c|} 
Standardized Coefficients \\
Beta
\end{tabular}} & \multirow{2}{*}{$\mathbf{t}$} & \multirow{2}{*}{ Sig. } \\
\hline & B & Std. Error & & & \\
\hline 1 (Constan) & 21.121 & 4.633 & & 4.559 & .000 \\
\hline $\mathrm{KO}$ & 1.705 & .188 & .807 & 9.074 & .000 \\
\hline
\end{tabular}

Dependent Variable : Organizational Citizenship Behavior

Dari tabel 4 maka dapat dibuat persamaan berdasarkan $\mathrm{Y}=\mathrm{a}+\mathrm{bX}$ maka $\mathrm{OCB}=21,121+1,705$. Makna konstanta (a) sebesar 21,121 adalah jika diasumsikan nilai komitmen organisasi adalah nol (0) maka Organizational Citizenship Behavior (OCB) sebesar 21,121. Nilai koefesien regeresi variabel komitmen organisasi sebesar 1,705 artinya setiap peningkatan komitmen organisasi sebesar 1 satuan maka akan meningkatkan OCB sebesar 1,705.

\subsection{Uji Determinasi $\left(R^{2}\right)$}

Uji determinasi dimaksudkan untuk mengetahui seberapa besar kontribusi variabel komitmen organisasi mempengaruhi Organizational Citizenship Behavior (OCB) pegawai pada BPTPM Kota Pekanbaru dengan melihat besar koefesien determinasi $\left(\mathrm{R}^{2}\right)$. Jika total $\mathrm{R}^{2}(\mathrm{R}$ Square) yang diperoleh mendekati 1 maka semakin kuat model tersebut menerangkan pengaruh variabel bebas terhadap variabel terikatnya. Jika mendekati nol (0) maka sebaliknya. Tabel 5 berikut akan menunjukan kontribusi variabel komitmen organisasi.

Tabel 5. Model Summary

\begin{tabular}{|c|c|c|c|c|}
\hline Model & $\mathbf{R}$ & $\begin{array}{c}\mathbf{R} \\
\text { Square }\end{array}$ & $\begin{array}{c}\text { Adjusted } \\
\text { R Square }\end{array}$ & $\begin{array}{l}\text { Std. Error of } \\
\text { the Estimate }\end{array}$ \\
\hline 1 & $.807 \mathrm{a}$ & .652 & .644 & 3.553 \\
\hline
\end{tabular}

Predictors: (Constant), Komitmen Organisasi

Berdasarkan tabel 5 diatas diketahui nilai $\mathrm{R}$ yang dihasilkan adalah 0.807 . Dalam hal ini maka dapat dikatakan hubungan antara komitmen organisasi dan OCB berkorelasi kuat sebesar 0,807. Selanjutnya nilai koefesien determinasi $\mathrm{R}^{2}$ ( $R$ Square) yang diperoleh sebesar 0,652 yang berarti variasi Organizational Citizenship Behavior (OCB) dapat 
dijelaskan oleh variasi komitmen organisasi sebesar $65,2 \%$. Atau dapat dikatakan variabel komitmen organisasi memberikan kontribusi terhadap variabel Organizational Citizenship Behavior (OCB) adalah sebesar $65,2 \%$.

\subsection{Uji Hipotesis}

Pada tabel 4 hasil regeresi sederhana menunjukan nilai t sebesar 9,074 dengan Signifikansi 0,000 . Diperoleh nilai t tabel dengan $\mathrm{df}=\mathrm{n}-\mathrm{k}-1=46-1-1=44$ pada taraf signifikansi 5\% sebesar 2,015. Maka t hitung $(9,074)>\mathrm{t}$ tabel $(2,015)$ atau signifikansi (.000) lebih kecil dari $\alpha=0,05$. Jadi posisi titik uji signifikansi berada pada wilayah penolakan Ho. Dapat disimpulkan Ha diterima yang artinya bahwa variabel komitmen organisasi berpengaruh positif dan signifikan terhadap variabel Organizational Citizenship Behavior (OCB) pegawai pada Badan Pelayanan Terpadu dan Penanaman Modal (BPTPM) Kota Pekanbaru.

\section{PEMBAHASAN}

Berdasarkan hasil uji statistik deskriptif diketahui tanggapan responden terhadap komitmen organisasi pada BPTPM Kota Pekanbaru mendapatkan skor yang tinggi. Komitmen organisasi pada penelitian ini diidentifikasi dengan kecocokan nilai dengan organisasi serta kepedulian terhadap organisasi, menjalankan kewajiban dan perasaan mereka yang memang seharusnya tetap bekerja pada organisasi tempat mereka bekerja sekarang dan merasa menjadi anggota organisasi adalah hal yang perlu serta keinginan untuk tetap bertahan. Dimensi komitmen yang terangkum dalam komitmen afektif, komitmen normatif dan komitmen berkelanjutan ini memberi arti bahwa pegawai BPTPM Kota Pekanbaru akan mengupayakan pencapaiaian tujuan organisasi dengan kemauan mengarahkan segala daya untuk kepentingan organisasi serta mempertahankan diri untuk tetap menjadi bagian dari organisasi.

Dengan adanya upaya dari pegawai untuk mengarahkan segala daya kemampuannya karena komitmennya yang tinggi terhadap organisasi maka secara teoritis sebagaimana diuraikan sebelumnya akan meransang timbulnya perilaku OCB. Sejalan dengan hasil penelitian ini yang membuktikan pengaruh komitmen organisasi berpengaruh secara signifikan terhadap munculnya OCB. Perilaku OCB yang timbul seperti membantu rekan kerja, melakukan tugas pekerjaan tanpa diminta, taat pada peraturan, melibatkan diri dalam kegiatan organisasi, toleransi terhadap konflik dan mengambil sikap serta meningkatkan kemampaunnya untuk kepentingan organisasi.

Hasil penelitian ini sesuai dengan hasil penelitian yang dilakukan Purba (2004) yang menyatakan terdapat pengaruh yang positif dan signifikan variabel komitmen organisasi terhadap OCB dan pernyataan School dan Schappe (dalam Purba, 2004) yang menemukan bahwa komitmen organisasi berpengaruh positif dan signifikan terhadap OCB. Kuatnya pengaruh komitmen organisasi ini tidak terlepas dari bentuk ikatan antara anggota organisasi dan organisasinya. Semakin kuat ikatan tersebut maka akan semakin memberi ruang peningkatan munculnya perilaku OCB.

Komitmen organisasi akan membuat pegawai memberikan yang terbaik kepada organisasinya. Pegawai yang memiliki komitmen yang tinggi akan lebih berorientasi pada kerja, akan cendrung membantu dan dapat bekerjasama. Hal ini tidak lain karena komitmen organisasi adalah bentuk ikatan psikogis pegawai tehadap oganisasi. Kenyataan ini juga didukung oleh profil responden pegawai BPTPM Kota Pekanbaru yang rata-rata dengan tingkat pendidikan yang tinggi dan masa kerja yang cukup lama, sehingga dengan komitmen yang tinggi maka daya yang dimiliki pegawai juga sangat memadai untuk mewujudkan tujuan organisasi. Dengan demikian komitmen yang terbentuk akan berpengaruh terhadap perilaku OCB pegawai yang lebih baik yang muncul tanpa adanya paksaan dan terpenting muncul dari keinginan diri pegawai yang memang ingin 
berperilaku demikian dengan berbuat lebih untuk organisasi secara sukarela.

Penelitian ini memperkuat teori dan hasil penelitian sebelumnya. Komitmen organisasi mempunyai pengaruh yang signifikan terhadap munculnya OCB. Hal ini dapat dipahami sebagaimana penjelasan sebelumnya komitmen organisasi sebagai bentuk keyakinan pegawai untuk tetap bertahan, melaksanakan kewajiban, terlebih mereka yang memiliki kesamaan dengan nilai-nilai yang diyakini organisasi akan membuat pegawai bekerja dengan sepenuh hati bahkan melebihi tuntutan deskripsi pekerjaan yang merupakan bentuk OCB. Dengan demikian semakin tinggi komitmen organisasi pegawai pada Badan Pelayanan Terpadu dan Penanaman Modal (BPTPM) maka Organizational Citizenship Behavior (OCB) akan semakin terwujud.

\section{PENUTUP}

\subsection{Kesimpulan}

Komitmen organisasi menjadi kondisi awal yang menguntungkan bagi munculnya Organizational Citizenship Behavior (OCB). Deskripsi statistik penelitian menunjukan variabel komitmen organisasi maupun OCB pegawai BMPTM berada pada katagori tinggi. Artinya secara umum BPTPM Kota Pekanbaru memiliki pegawai dengan komitmen organisasi dan OCB yang tinggi. Komitmen organisasi berpengaruh positif dan signifikan terhadap OCB pegawai BPTPM Kota Pekanbaru. Kondisi ini menunjukan jika komitmen organisasi pegawai BPTPM Kota Pekanbaru meningkat maka OCB pegawai BPTPM Kota Pekanbaru juga meningkat. Variabel komitmen organisasi memberikan kontribusi pengaruh terhadap variabel Organizational Citizenship Behavior (OCB) sebesar 65,2\%. Dengan demikian sisa $34,8 \%$ merupakan pengaruh faktor lain yang tidak diteliti pada penelitan ini.

\subsection{Saran}

Komitmen organisasi memberi kontrobusi yang cukup besar terhadap munculnya OCB pegawai BPTPM Kota Pekanbaru. Artinya BPTPM Kota
Pekanbaru perlu memelihara komitmen pegawai yang ada agar tidak mengalami penurunan bahkan harus ditingkatkan. Hal ini bisa dilakukan seperti dengan mengadakan pelatihan bagi pegawai untuk memperluas keterampilan mereka, serta membantu pegawai untuk melanjutkan pendidikan dan pengembangan diri.

Untuk penilitian lebih lanjut disarankan meneliti faktor lain yang berpengaruh terhadap OCB khususnya pada berbagai instansi publik. Hal ini dikarenakan masih minimnya penelitian OCB pada instansi publik yang selama ini OCB lebih banyak dikenal atau diteliti pada organisasi/ instansi swasta. Selain itu tehnik pengumpulan data hendaknya lebih diperdalam dengan melakukan observasi dan wawancara.

\section{DAFTAR PUSTAKA}

Budihardjo, Andreas. 2014. Organisasi Menuju Pencapaian Kinerja Optimum. Jakarta: Prasetiya Mulya Publishing

Darmawan, Didit , 2013. Prinsip-prinsip Perilaku Organisasi. Surabaya : Pena Semesta

Darto, Mariman. Peran Ornizational Citizhenship Behavior (OCB) Dalam Peningkatan Kinerja Individu di Sektor Publik: Sebuah Analisi Teoritis dan Empiris, Jurnal Borneo Administrator, Volume 10 No. 1, 2014.

Purba, Eflina Debora. Pengaruh Kepribadian dan Komitmen Organisasi Terhadap Organizational Citizenship Behavior (OCB), Makara, Sosial Humaniora, Vol. 8, No. 3, Desember 2004 : 105-111.

Sopiah, 2014, Perilaku Organisasional, Yogyakarta : Andi.

Sutrisno, Edi, 2013, Manajemen Sumber daya Manusia. Jakarta :Kencana.

Titisari, Purnamie, 2014. Peranan Organiszational Citizenship Behavior (OCB). Mitra Wacana Media: Jakarta.

Umar, Husein, 2003, Metode Riset Perilaku Organisasi, Jakarta : PT. Gramedia Pustaka Utama 
Waspodo, Agus AWS dkk, 2012. Pengaruh kepuasan kerja dan Iklim Organisasi Terhadap Organiszational Citizenship Behavior (OCB) karyawan pada PT. Trubus Swadaya, Jurnal Riset Manajemen Sains Indonesia (JRMS)| Vol.3, No. 1 